\title{
HOW TO INVESTIGATE THE LOCAL AND GLOBAL CHANGE POTENTIAL OF QUESTIONING SEQUENCES IN EXECUTIVE COACHING? A CALL FOR INTERDISCIPLINARY RESEARCH
}

\author{
Eva-Maria Graf \\ University of Klagenfurt \\ eva-maria.graf@aau.at \\ Frédérick Dionne \\ University of Klagenfurt \\ frederick.dionne@aau.at \\ Thomas Spranz-Fogasy \\ Leibniz-Institute for the German Language \\ spranz@ids-mannheim.de
}

\begin{abstract}
Coaching outcome research convincingly argues that coaching is effective and facilitates change in clients. While coaching practice literature depicts questions as key vehicle for such change, empirical findings as regards the local and global change potential of questions are so far largely missing in both (psychological) outcome research and (linguistic and psychological) process research on coaching. The local change potential of questions refers to a turn-by-turn transformation as a result of their sequentiality, the global change potential is related to the power of questions to initiate, process and finalize established phases of change. This programmatic article on questions, or rather questioning sequences, in executive coaching pursues two goals: firstly, it takes stock of available insights into questions in coaching and advocates for Conversation Analysis as a fruitful methodological framework to assess the local change potential of questioning sequences. Secondly, it points to the limitations of a local turn-by-turn approach to unravel the overall change potential of questions and calls for an interdisciplinary approach to
\end{abstract}


bring both local and global effectiveness into relation. Such an approach is premised on conversational sequentiality and psychological theories of change and facilitates research on questioning sequences as both local and global agents of change across the continuum of coaching sessions. We present the TSPP Model as a first result of such an interdisciplinary cooperation.

Keywords: Coaching; questioning sequences; Conversation Analysis; local and global effectiveness; interdisciplinarity; TSPP Model;

* We want to thank the anonymous reviewer for valuable comments on the earlier version of this paper as well as Melanie Fleischhacker for her most appreciated support in the revision process.

\section{Setting the stage: Questioning sequences in executive coaching}

Executive coaching is a burgeoning professional helping interaction between a trained coach and a client with managerial responsibility set in the organizational world. The overall goal of coaching is to facilitate change and transformation in and for the client as regards work-related themes such as high performance or leadership issues. The international spread and growing relevance of coaching have, however, not been met with a heightened empirical interest in coaching in the academic world. Unlike neighboring professional helping formats such as psychotherapy, (executive) coaching is still underresearched. While the overall effectiveness of executive coaching (i.e. its global change potential) has by now been verified in psychological coaching outcome research in the context of established phases of change, there is little research on the coaching process itself and on what makes coaching effective, that is, what allows for clients' change and transformation on the local level of the concrete interactions between coach and client. The latter is the focus of a more recent process research paradigm in coaching, which targets, among other objectives, the microanalytic sequential process of coaching. The linguistic or conversation analytic perspective on coaching forms part of this paradigm (Graf 2015, 2016, 2019). With its focus on what coach and client do together verbally (and non-verbally) on the interactional level on a turn-by-turn basis, such a conversation analytic perspective addresses discursive practices in their sequentiality as the local building-blocks of coaching and as facilitators of its local effectiveness. Up to this moment, research on this sequentiality and on the global effectiveness of coaching have not been brought into relationship. Therefore, while executive coaching is the particular professional helping interaction under scrutiny here, questions, to be more precise questioning sequences, are the discursive practice we target.

Executive coaching practice literature and training manuals insinuate that questions are omnipresent and omnirelevant in coaching, which means questions are portrayed as key agents of the overall effectiveness of coaching. Yet, their claims have so far not not been empirically corroborated. Whereas 
questions have already been established as omnipresent across mundane and professional formats and as carrying out important tasks on the thematic, interactive and format-specific levels in Conversation Analysis, questions in coaching have so far received little empirical attention. More specifically, while the (local) change potential of questioning sequences has been conversation analytically assessed for neighboring helping professional interactions such as psychotherapy (see e.g. various publications by Peräkylä and Worsøe \& Jensen, this issue), hardly any research exists on the transformative power of questions in executive coaching.

Our research interest was sparked by the discrepancy between the attested importance of questions in coaching due to their change potential and the unsatisfying research situation (Graf \& Spranz-Fogasy 2018a). First empirical results from a purely quantitative perspective show that questions represent a central steering element in coaching (Deplazes 2016), and isolated studies with non-authentic coaching data evince differences between solutionoriented and problem-oriented questions (various publications by Grant and colleagues). However, there are hardly any insights into questions as a naturally occurring discursive and sequential practice in executive coaching, how this practice unfolds within and across the professional interaction-type and how questioning practices in their sequentiality contribute to the local and, consequently, the overall global effectiveness of executive coaching.

In order to fully unravel the transformative potential of questioning sequences as local and global agents of change across entire coaching processes, that is, to close this research gap, we suggest that linguistic and psychological analyses must join forces. This programmatic paper advocates for such an interdisciplinary approach based on insights from psychology and its normative-theoretical focus on phases of change and insights from Conversation Analysis and its descriptive-phenomenological focus on transformative sequences. It presents the Turn-Sequence-Phase-Process (TSPP) Model of Coaching (Deplazes, Graf \& Künzli 2018) as a first interdisciplinary product of such a linguistic-psychological cooperation in the context of coaching research. Focussing on turns, sequences, phases and processes in coaching (conversations), the model can serve as a matrix to empirically assess the local and global transformational potential of discursive practices such as questioning sequences in coaching. On a more general level and beyond its current purpose in the context of investigating questioning sequences, the model allows to address both, effectiveness and sequentiality in coaching and thus advances our understanding of the coaching process at large.

The article is structured as follows: Section 2 introduces the helping format 'executive coaching' as the professional interaction-type we target. The state of the art in coaching (outcome and process) research in psychology and linguistics is outlined with a particular focus on insights into its global 
and local effectiveness across turns, sequences, phases and entire coaching processes. Next, Section 3 details how coaching practice literature portrays questions as omnipresent and omnirelevant phenomena and as key agents of change. It also aggregates first findings on questions from coaching outcome and process research. A stark contrast between the idealized claims and hypotheses in coaching practice literature and the existing empirical findings on questions as local and global agents of change emerges. In light of such a meager research situation, Section 4 turns to conversation analytic research on questions in surrounding professional (in particular therapeutic) interactions. While practice literature and outcome research focus on isolated questions or question types, Conversation Analysis stresses the inherent sequential organization of questions in the context of questioning sequences. Their formal, functional and interaction-type specific characteristics are discussed focusing particularly on the local transformative power that emerges from the sequential organization of questioning practices as adjacent turns across a conversational continuum. Yet, while analyzing such a turn-by-turn organization of questioning practices allows to unravel locally successful (i.e. change-inducing) sequences, existing conversation analytic research does not go beyond this level of effectiveness. It does not allow to assess the global effectiveness of questioning sequences spanning the continuum of sessions in the context of established phases of change. Section 5 thus brings the various lines of argumentation together and calls for an interdisciplinary approach. The article ends with presenting the jointly developed TSPP Model (Deplazes et al. 2018) for coaching research, which integrates relevant psychological and linguistic insights into the morphology of change and thus allows to address the local and global change potential of questioning sequences in executive coaching.

\section{Coaching. Research into its global and local effectiveness}

Coaching is an umbrella term for widely differing counseling activities situated in the larger terrain of (organizational) development tools, techniques and services, which are at times hard to discriminate. In its current practice, coaching has many conceptual and professional roots such as social psychology, learning theory or theories of human and organizational development and applies a great variety of interventions, often originating in psychotherapy, management theory and counseling (Bachkirova et al. 2018). Yet, despite its internationally growing popularity and acceptance, "the concept of coaching as profession is still relatively new" (Bachkirova et al. 2018:xiv). According to Stein (2007) and Drath (2012), the most widely practiced types of coaching are 'life coaching' and 'personal coaching' on the one hand and 'business coaching' or 'executive coaching' on the other. While the first pair focuses on personal and life issues, the second addresses work-related issues such as leadership performance; the article is concerned with executive coaching. 
Executive coaching transpires in and through a series of conversations and coaching sessions between a coach and a non-clinical client with managerial responsibilities and tackles clients' work-related issues. It is (linguistically) conceptualized as a professional and/or institutional helping interaction (Drew \& Heritage 1992, Mondada 2013, Graf et al. (eds.) 2014, Graf \& Spranz-Fogasy 2018b) and more specifically as a type of counseling located in the organizational realm (cf. Kallmeyer 2000, Graf 2017, Pick (ed.) 2017). The overall goal of coaching is to allow for change in the client: "(p)eople come to coaching for lots of different reasons, but the bottom line is change" (Whitworth et al. 1998:xix). Theoretical models of change thereby predispose an action logic, that is, clients have to pass through specific (developmental) stages or phases such as the pre-decisional, motivational phase, the preactional, volitional phase, the actional phase and the post-actional evaluation phase as elaborated in the Rubicon model (cf. Greif \& Benning-Rohnke 2015). The observable part of a client's (overall) change process is the conversation with their coach, whose local utterance-by-utterance transformation underlies this global process of change.

While coaching research has recently picked up momentum, coaching still lacks a sound academic foundation with significant gaps in the available research. Particularly when juxtaposed with the research situation in other helping professions such as psychotherapy, research on coaching is (still) less established and prominent; reasons for this lie in its practical origin and multidisciplinarity (Fietze 2017). Due to certain parallels between coaching and psychotherapy, existing research designs and questions often replicate available therapeutic research paradigms. In this vein, coaching research exists in the forms of outcome research and process research (Fillery-Travis \& Cox 2018, Wegener et al. (eds.) 2018). Particularly in the field of quantitative outcome studies, coaching research has recently gained considerable ground (Kotte et al. 2016, Fillery-Travis \& Cox 2018). Five meta-analyses prove its effectiveness, that is, coaching facilitates (global) change in and for the client across the entire coaching process (De Meuse et al. 2009, Theeboom et al. 2014, Jones et al. 2016, Sonesh et al. 2015, and Burt \& Talati 2017) (see Graf \& Dionne under review for a current overview). Effectiveness is defined and assessed across these meta-analyses as individual learning and development, improvement in clients' performance and skills, positive results for the organization, but also an improved well-being and coping, general improvement in work- and career related attitudes as well as goal-directed self-regulation. However, distinct research gaps exist, particularly as regards to how and where this global effectiveness emerges or is co-constructed locally along the coaching process. As De Haan and colleagues state, in order 
... to understand the impact and contribution of executive coaching $\ldots$ it is not enough to just understand general effectiveness or outcome. One also has to inquire into and create an understanding of the underlying coaching processes themselves, from the perspectives of both clients and coaches (2010: 110, see also Theeboom et al. 2014:14).

Coaching process research has more recently started to engage in this 'how/ where' of coaching effectiveness (see Wegener et al. (eds.) 2018). Developed in analogy with psychotherapy process research (see Elliott's 2010, 2012 "change-process research paradigm"), coaching process research is fed by various disciplines such as psychology and linguistics, applies quantitative and qualitative methods and exists in the settings: 'process-outcome design', 'helpful factors design', 'significant event research design' and 'microanalytic sequential process design'. Psychological coaching process research investigates the interaction or process as such and addresses, for example, significant events (Wegener 2019) or interventions in coaching (Deplazes 2016). Most prominently, it targets success factors in coaching within the process-outcome design (see Künzli 2013). Success factors, theoretically and normatively developed in established models of change in psychology, explicate how clients proceed effectively from realizing a desire for action to taking such action, evaluating the action and maintaining the action (e.g. Greif \& BenningRohnke 2015). The empirical focus is on assessing frequency and intensity of success factors across recognized process phases of change as a measure for coaches' responsiveness regarding the theoretical underpinning of coaching (Behrendt 2006, Greif et al. 2012, Tertocha 2016). However, psychological coaching process research does not look into the local, sequential organization of these phases of change.

Linguistically based coaching process research in its descriptivephenomenological stance forms part of the 'microanalytic sequential process design' and addresses how coaching as interactive and communicative process emerges from the verbal, sequentially organized, turn-by-turn interaction. Premised on insights from conversation analysis in more established professional helping formats such as psychotherapy, it investigates the local and processual co-construction of the coaching interaction by coach and client (see e.g. the Basic Activity Model of Coaching (Graf 2015, 2019)). As a professional helping interaction, it is based on an endemic asymmetry between coach and client that primarily centers on notions of 'knowledge' and 'expertise' (Heller 2007, Koester 2010): While coaches dispose of expert knowledge as regards professional theories and models (e.g. models of change and transformation), clients dispose of subjective, experiential knowledge about their lives and their concerns (Sarangi 2001). The knowledge asymmetry between coach and client, the ensuing differences regarding problem solving capacities as well as perspectives constitute the essence of coaching and its 
raison dêtre (Kallmeyer 2000, Deppermann 2015). Knowledge asymmetry emerges on the level of the concrete (coaching) conversation in differing epistemic authorities, rights and obligations of the participants (Heritage 2018, Raymond 2018). Linguistic coaching process research looks into the varying degrees of thematic and interactive control over the coaching conversation via agenda setting and interaction orchestration in general and, more concretely, via applying discursive practices such as questions with specific communicative intentions (Spranz-Fogasy 1992, Tiittula 2001, Mönnich 2004, Mayes, this issue) that contribute to the local, utterance-by-utterance process of change (Peräkylä 2019). How coaches locally dominate and guide the conversations is molded by their professional agenda that underlies how the goal of the interaction (i.e. clients' global change) is accomplished. The professional agenda predetermines and underlies the conversational development of coaching alongside its internal tasks and action logic; due to the systematic asymmetries and differing dominance as endemic components of professional interaction, the coaches have the power to ensure the compliance with the professional agenda (Tiittula 2001:1362), that is, to exploit the local change potential. As will be argued in Section 4, questioning practices serve as central local steering elements and thereby contribute to the local, but also the global effectiveness of coaching.

To sum up, while outcome research documents that the coaching process is effective (i.e. allows for clients' change across pre-established phases of change) and that certain success factors contribute to this global effectiveness, coaching process research adds insights into the intensity and frequency of such success factors as well as into the sequential organization of the coaching conversations (in its turn-by-turn organization) and its local effectiveness. A necessary next step in coaching research is to integrate effectiveness and sequentiality of coaching. This is, however, empirically challenging given that coaching resides in a complex reciprocity of the participants' communicative actions. Kramer and Stiles (2015) refer to this challenge with the concept of 'appropriate responsiveness' (AR). AR, originally discussed in psychotherapy research, means that professional helpers such as coaches aim to do what is best for clients in each and every moment of their interactions with them. What is currently the best, that is, the most appropriate and effective, is decided both in response to the underlying professional theory (e.g. theory of change) and in response to the client on a moment-to-moment basis. Examples for appropriate responsive behavior include active listening, adjusting interventions already in progress and - at the core of this paper - asking appropriate questions. The latter entails engaging in questioning practices that allow for clients' change both on the global level as regards the overall effectiveness and on the local level regarding the turn-by-turn sequentiality of the coaching conversation. In Section 5, the paper therefore presents the TSPP Model as a solution to empirically integrate effectiveness and sequentiality of coaching. The model, 
based on turns, sequences, phases and entire coaching processes, is premised on interdisciplinary insights from psychology and linguistics and can serve as a matrix for analyzing the local and global change potential of questioning sequences. More generally, it allows for addressing appropriate responsive behavior by coaches.

Before Section 5 further describes the TSPP Model, the next two sections showcase questions and their relevance for the effectiveness of coaching. While coaching practice literature claims that questions are omnipresent and omnirelevant, empirical findings that illuminate the local and global change potential of questions are largely missing in coaching research (Section 3). A first step to close this research gap is to use insights from Conversation Analysis into the local transformative potential of questioning sequences from other helping professions (Section 4). However, their global change potential, that is, their contribution to global effectiveness, is beyond the scope of conversation analytic research. The need to combine both and possible ways to do it will be addressed in Section 5 .

\section{Questions in executive coaching. Practical claims and empirical findings of their change potential}

Questions represent the most widely discussed intervention across professional and institutional formats (Tracy \& Robles 2009:131). Coaching, too, has a myriad of books and manuals offering advice to coaches as to what types of questions to ask. Questions are portrayed as a guarantor for successful coaching (i.e. for global change potential) and as the central and most powerful intervention tool (i.e. for local effectiveness): Loebbert and Wilmes (2013:38) frame questions as the silver bullet for client's explorations, Fischer-Epe (2012:60) argues that questions are a central steering element of the coaching process, and Schreyögg (2012:269) characterizes asking questions as a coach's most important task. Accordingly, these books and manuals on coaching offer extensive lists of question types, categorized via decontextualized functions and illustrated via invented examples in a monological form. It is implied that good coaching means asking many questions and making use of such variety (Wehrle 2012, Geißler 2016). Practice literature also advises practitioners on how to do questioning, for example, to ask one question at a time or to concentrate on questions that start with 'what' (cf. Bungay Stanier 2016). Replicated across practice literature and training manuals is a positive assessment of open-ended questions as inviting detailed answers, while closed questions are disfavored as they are supposed to close down the conversation and leave the client no space for reflection (e.g. Fischer-Epe 2012, Schreyögg 2012). Such evaluations regarding the relevance of questions in coaching practice literature is based on the respective authors' practical experiences as coaches and/or their personal assessment, but not on empirical findings. A similar picture emerges from professional coaching trainings. 
Moving away from coaching practice literature and training manuals to coaching research, a very different picture emerges. Questioning practices have so far received hardly any academic attention (cf. Graf \& Spranz-Fogasy 2018a) and neither coaching outcome nor coaching process research have systematically investigated the authentic use of questioning practices in their different forms, functions and specificities. Coaching outcome studies exclusively address solution- vs. problem-oriented questions and their influence on the (global) effectiveness of coaching. While research by Wehr (2010), Grant and O'Connor (2010), Grant (2012), Neipp and colleagues (2015), Braunstein and Grant (2016) as well as Grant and O'Connor (2018) has revealed that solution-oriented questions in contrast to problem-oriented questions enhance clients' positive affect, Theeboom and colleagues (2016) as well as Grant and Gerrard (2019) could show that solution-oriented questions or a combination of problem- and solution-oriented questions also decrease clients' negative affect and positively impact clients' cognitive flexibility. These studies relate pre-established and isolated types of questions, whose exact wording is laid out in coding schema, to certain effects on clients' affect, cognition or behavior. They apply quantitative methods in the realm of psychology, focus on question types in coaching, but do not consider the processual and sequential character of questioning in coaching, which means they treat questions as isolated linguistic strategies applied by coaches. In addition, they all work with students instead of 'real coaches' and 'real clients'. While all authors agree that "effective questioning lies at the very heart of the coaching conversation" (Grant \& O'Connor 2010:102; see also Theeboom et al. 2016:461), psychological outcome research faces other, up-to-now unanswered questions such as "(b)ut what constitutes 'effective' questioning in coaching?" (Grant \& O'Connor 2010:102). Besides such isolated studies dedicated exclusively to questions in coaching, there is some research that focuses on certain questions next to other interventions. For example, Newsom and Dent (2011) analyze coaching behavior and coaching actions of executive coaches and thereby investigate - inter alia - asking open questions. As the most frequently named actions in their interviews with around 130 coaches, the authors list 1) establishing trust, honesty, and respect, 2) using open-ended questions, and 3) clarifying and understanding client concerns and challenges (ibid:18). The study treats questions as one (important) intervention among other interventions, and thus aims to draw a realistic picture of coaches' overall activities. Yet, a retrospective report on what one (presumably) has done - in addition to exclusively focusing on the coach and thus proposing a monological perspective on coaching - must be considered a major drawback from an interaction-based understanding of coaching. Overall, the empirical situation of questions in psychological coaching outcome research is not satisfying and does not reflect the significance and presumed effectiveness of questions as claimed in the coaching practice literature. Large-scale findings 
on questions in their naturally occurring variety and complexity are missing so far.

In the context of psychological coaching process research, only Deplazes (2016) addresses questions and offers first empirical insights into authentic questioning in her video-analysis. Her analysis on interventions and tools, which draws on, among other methods, qualitative content analysis (Mayring 2010) of authentic coaching, evinced that questions indeed represent a central intervention and that responses to closed questions do not significantly deviate in their response length in comparison to open questions. By including responses to the coded questions in her analytic procedure, Deplazes does touch upon the sequentiality of questions. Nevertheless, given that her analysis aims at interventions and tools in coaching in general, the treatment of questions necessarily remained on the surface. In linguistic coaching process research, so far only two studies looks into questioning practices in coaching: Spranz-Fogasy and colleagues (2019) compare the local, in-situ construction of 'requesting examples' in psychodiagnostic interviews and coaching interactions and carve out interaction-type specific differences with regard to the use of requesting examples across the two helping formats (for details see Section 4). Besides their focus on only one particular questioning type, Spranz-Fogasy and colleagues (2019) are interested in the interactiontype specificity of requesting examples rather than their local (and global) change potential. Graf and Kabatnik (in prep.) and Kabatnik and Graf (in prep.) investigate differences and commonalities between solution-oriented questions in coaching and psychotherapy and address their respective local change potentials.

In sum, despite their omnipresence in coaching practice literature, questions in coaching are still largely neglected in both psychological and linguistic coaching research. In particular, it has never been investigated how questions in their sequential organization contribute to the local and global effectiveness of coaching. As stated in a recent overview article by Graf and Spranz-Fogasy (2018a), neither coaching outcome nor process research address vital issues such as the co- and con-textual embedding of questions in the ongoing coaching process or interaction. A similar critique is found in McGee (1999), McGee and colleagues (2005) and James and colleagues, who argue that " $(w)$ hile we feel it is helpful to examine question types, it is relevant to note that examining single questions in isolation is overly simplistic due to their impact being a feature of how they are combined and sequenced" (2010:83). To begin closing the aforementioned research gap, we advocate to avoid a decontextualizing, monological perspective on questions. Instead, we suggest Conversation Analysis as a fruitful methodological framework to investigate both the natural occurrence of questioning practices in their sequential set-up of 'question - response - follow-up' within a coaching conversation and the local change potential of questioning sequences entailed 
in such sequentiality (Peräkylä 2019). Regarding questions as part of turnby-turn sequences is concurrently a first step to bring them into relation with larger units such as phases and the entire coaching process, which is the underlying objective of the current endeavor.

\section{Questioning sequences in Conversation Analysis. A focus on local change potential}

Against the background of our linguistic understanding of coaching as a co-constructed professional helping conversation, analyzing discursive practices such as questions requires considering them in the co-text of their preceding and following turns. The empirical focus then shifts from 'questions' to 'question-answer-third position reaction sequence' - in other words, to questions in their sequential set-up (Schegloff 2007, Stivers 2013, Graf \& Spranz-Fogasy 2018a). Sequentiality represents a core tenet of Conversation Analysis (Schegloff 2007, Sidnell \& Stivers (eds.) 2013): each turn has a retrospective and prospective dimension, which is thematically and interactively linked to its prior turn and to the turn that immediately follows due to the underlying axiom of conditional relevance. As Stivers formulates it (2013:191), "turn-constructional units, and the actions produced with them, are proffered by reference to what came before and affect what comes next." The entailed, local turn-by-turn transformation contributes to the process of change in more macroscopic time, spanning the continuum of coaching sessions (Peräkylä 2019), i.e. the sequentiality of turns functions as a local agent of change, that is as a local agent of the effectiveness of the professional interaction both within and across sessions (e.g. Muntigl 2013, Voutilainen et al. 2018). However, what has not been pursued in Conversation Analysis is whether and how such sequentiality and its local change potential contribute to patients'/clients' global change.

Conversation Analysis has widely researched questioning practices across both mundane and professional settings, with a particular focus on helping formats (see e.g. Barthesagi 2009, Weatherall \& Gibson 2015, Mack et al. 2016 on questions in therapy; Spranz-Fogasy 2005, 2010 and Heritage 2010 on questions in doctor-patient interaction; and Peräkylä 1995 and Sarangi 2010 in counseling). In what follows, we will summarize their insights and findings on questioning sequences in their formal, functional, and interaction-type specific morphologies. This knowledge underlies the missing conversation analytic (process) research on questioning practices in (executive) coaching in terms of their local effectiveness or change potential.

Questions are linguistically defined according to formal aspects such as lexical criteria (wh-questions) and syntactic criteria (verb-first and declarative questions) (Tracy \& Robles 2009, Stivers 2010, 2018). These different question types entail an inherent asymmetry according to different stocks of knowledge in and epistemic rights of the participants (Heritage 2010, Spranz-Fogasy 
2010, Hayano 2013). In doctor-patient interaction, Spranz-Fogasy (2005), for example, established the question types 'precision questions', associated with the patient's thematic control and knowledge, and 'completion questions', associated with the doctor's knowledge. The formal construction of questions also manifests a preference organization for the construction of answers (Pomerantz \& Heritage 2013, Clayman \& Loeb 2018). Preferred reactions follow the progressivity principle of interactions (Stivers \& Robinson 2006), but there are also various types of dis-preferred responses according to MacMartin (2008), Lee (2013) and Stivers (2018): non-answer-responses, answer-like responses such as refocusing and transformative responses. Dis-preferred answers/responses can attest to unsuccessful question-answer sequences, and the set-up of the third position determines the further process of the interaction. Both the varying levels of knowledge and understanding addressed with the help of wh-questions, verb-first questions and declarative questions as well as their varying strength to elicit a specific response in the client influence the local change potential of the respective question types.

As regards the functional dimensions of questions or questioning practices, Steensig and Drew (2008:7) generally claim that "(a)sking a question is not an innocent thing to do.” According to Köller (2004:662), questions originate in the human aptitude to initiate hypothetical imagination processes prone to transform into self-reflection processes; questions allow for new experience given that they entail a change of perspective and a possible change in one's point of view. Questions help to localize knowledge gaps, to express knowledge requirements, to articulate one's interest in reasons, to relate to the present as well as to the past or to do repair-related actions in the context of aided communication (see Mayes, this issue). In so doing, questions perform moment-by-moment informational and relational management, given that the epistemic authority to ask a question and the obligation to respond originate in and mold the relationship between the communicative partners (Stivers 2018). These general characteristics of questions are particularly pronounced in professional helping formats such as counseling and psychotherapy, where questions characterize core interventions as they invite self-reflection and thus induce (global) change (Bercelli et al. 2008, Muntigl \& Zabala 2008, Stokoe \& Sikveland 2016, Spranz-Fogasy et al. 2019). Muntigl and Zabala (2008:188) state, "(a)dequate reflection on one's experience is often seen as a stepping stone to change because reflection can allow the client to construe his or her life and social relationships in additional and alternative ways". As shown by Peräkylä and colleagues for psychotherapeutic interactions in various publications, the sequential set-up of questioning practices ensures their local effectiveness and also initiates and underlies change on a more global level: it helps experts to pursue their professional agenda by setting a specific kind of reply as conditionally relevant (Heritage 2012) and allows the participants to co-construct intersubjectivity. Due to their nature as necessary adjacency 
pairs, question-answer sequences are paradigmatic for the dictum of the local effectiveness: New knowledge and insights are co-constructed for patients/ clients on the conversational micro-level of interaction. In other words, (local) change results above all from the sequential, turn-by-turn organization of helping conversations via questions (and other communicative practices such as interpretations or (re)formulations; see Marciniak et al. 2016). Individual reflection processes as well as the status of mutual understanding as traces of new or transformed knowledge thereby show in all forms of responses when the follow-up reaction in third position is considered (Schegloff 2007, Peräkylä 2011, 2019). Given that questions function as a principal communicative steering practice in (professional) interactions (cf. Tsui 1992, Freed \& Ehrlich (eds.) 2010, Heritage 2010, Spranz-Fogasy 2010, Hayano 2013, Drew \& Couper-Kuhlen 2014), they must be considered key agents of local (and global) change (but see Worsøe \& Jensen, this issue on the client asking the therapist questions and how such reverse questioning affects the ecology of therapeutic practice).

Finally, Conversation Analysis is concerned with the interaction-type sensitivity of questioning practices (Tracy \& Robles 2009; see typologies for psychotherapy in Mack et al. 2016 and for doctor-patient interaction in SpranzFogasy 2010 and Heritage 2010). Specific question types are used more or less frequently in distinct sequential contexts and with distinct functions even in relatively 'close' interaction types such as psychoanalytic conversations, cognitive psychotherapy or resource-oriented counseling (Weiste \& Peräkylä 2013). A case in point is the study by Spranz-Fogasy and colleagues (2019) that contrasts requesting examples - understood as retrospective requests from the therapist/coach to the patient/client to elaborate their directly preceding utterance via an exemplary concretization - in psychotherapy and executive coaching. The findings attest to similarities, but also to interactionspecific differences as regards the thematic, sequential and interactive design of this particular questioning practice between the two types of helping conversations: Both helping formats make use of requesting examples as a way to invite and sketch a more specific picture of patients'/clients' (so far only generally or vaguely described) situation and of patients'/clients' manner of emotional and cognitive engagement with such examples; in both formats, patients'/clients' choice of a particular event as an exemplification of some general behavior invites and initiates a further exploration and reflection upon this event and related topics. As a result, the proffered examples lead towards developing alternative ways of feeling, perceiving and possibly acting and thus entail transformative potential. However, Spranz-Fogasy and colleagues' results also attest to significant differences regarding local change potential: first of all, psychotherapeutic interactions substantially thematize facets of the patient's personality, whereas coaching conversations only do so in passing and rather concentrate on clients' professional role. Secondly, while patients' 
subjective experience has yet to be carved out in the therapeutic context, coaching clients "come equipped" with a readiness to change. The sequential trajectory of requesting examples in both formats reflects such initial resistance in therapy and fundamental willingness to change in coaching, thus attesting to an interaction type specific difference in local change potential (see Table 1 below): responses (second-turn position) to requesting examples are tackled differently on the interactive level by patients and clients in the sense that clients show more readiness to exemplify (problematic) behavior, and, consequently, achieve their goal to change more quickly. Due to executive clients' general greater willingness to engage in example work, the study evinced more requesting examples by coaches and more responsive behavior in clients in the form of concrete examples than Spranz-Fogasy et al (2019) found in the psychotherapeutic data.

\begin{tabular}{|l|l|l|}
\hline & OPD & Coaching \\
\hline Position 1 & Therapist reformulates or asks a question & Patient responds, but response is too vague or \\
\hline Position 2 & $\begin{array}{l}\text { Client reports of their subjective experience of } \\
\text { an event }\end{array}$ \\
\hline Position 3 & Therapist requests an example & Coach requests an example \\
\hline Position 4 & $\begin{array}{l}\text { Patient offers an example (or initially resists, } \\
\text { but provides an example following the } \\
\text { therapist's insistence) }\end{array}$ & Client offers an example \\
\hline Position 5 & $\begin{array}{l}\text { Therapist focuses on the experiential and } \\
\text { emotional aspects of the example }\end{array}$ & $\begin{array}{l}\text { Coach deepens the discussion of the } \\
\text { experiential and emotional aspects of the } \\
\text { example }\end{array}$ \\
\hline$\ldots$ & $\begin{array}{l}\text { Reflection on example and development of } \\
\text { alternative perspectives and actions }\end{array}$ & $\begin{array}{l}\text { Solution-focused discussion between Coach } \\
\text { and Client }\end{array}$ \\
\hline
\end{tabular}

Table 1: Comparative sequential layout of 'requesting examples' in psychotherapy and coaching (adapted from Spranz-Fogasy et al. 2019)

Such interaction-type specific behavior of formally and functionally similar question types justifies our argument for a close-up empirical analysis of questioning sequences in executive coaching irrespective of existing research in closely-related interaction types.

To summarize, conversation analytic research on questions has revealed how crucial the practice is in orchestrating talk-in-interaction, managing power, and co-constructing (new) knowledge. It has also shown how formal, functional and interaction-type specific morphologies influence the local change potential of questioning sequences. Studies on questions in other helping professions such as psychotherapy have evinced that the sequential nature of questions entails a transformative potential to enable change in patients on the local level of the concrete interaction. Yet, although (some) recent CA research has shifted the scope of analysis to "supra-session courses of action" (Bercelli et al. 2013), more longitudinal investigations of (local) change in interaction, that is, research on processes of change taking place over several sessions, awaits further elaboration (Peräkylä 2019:277). Concurrently, 
the link between such locally and sequentially emerging change (possibly spanning the continuum of sessions) and global effectiveness in the sense of passing through established phases of change cannot be established within Conversation Analysis. This approach does not allow to go beyond insights into the turn-by-turn effectiveness of discursive practices such as questioning sequences. Nevertheless, the following section will offer first solutions how the relation between their local and global change potential can be investigated.

\section{Questioning sequences as local and global agents of change in executive coaching. A call for interdisciplinary research}

As has materialized from the previous sections, psychological outcome research argues for the global effectiveness of coaching through established phases of change, while linguistic process research focuses on the local effectiveness of coaching in its turn-by-turn co-construction and the ensuing thematic and interactive constraints entailed in each turn. In their respective normativetheoretical and descriptive-phenomenological perspective on coaching, psychology and linguistics address different aspects of coaches' appropriate responsive behavior towards their clients. As regards questions and their hypothesized and idealized relevance for coaching and its effectiveness, only Conversation Analysis provides detailed formal, functional and interactiontype specific information on questioning sequences in professional helping formats. Questioning sequences have thereby been empirically established outside of coaching - as local agents of change in their turn-by-turn sequential organization.

However, as has already been indicated in Section 2, up until now, established phases of change (i.e. global effectiveness) and the sequential coconstruction of coaching conversations (i.e. local effectiveness) have not been brought into relationship. In order to investigate the interaction-type specific local and global change potentials of questioning sequences (spanning the continuum of coaching sessions), linguistics and psychology must join forces. As a first step, Deplazes, Graf and Künzli (2018) developed the TSPP Model of Coaching. In a nutshell, this model serves as a tool to better understand the structural components of coaching interactions and aids researchers in their quest to investigate the change process along the levels of turns, sequences, phases and entire processes. To this end, it integrates the predisposed action logic of change and the predisposed action logic of verbal interactions.

As the name indicates, the Turn-Sequence-Phases-Process Model builds from the smallest conversational unit to the largest in accordance with the chronological and action logical development of the coaching conversation (Deplazes et al. 2018:77). While the turn makes sense on its own, it is also part of a sequence as a result of the principle of conditional relevance and of the thematic connection between turns. Several sequences then form complex phases, which are determined by the structural organization of coaching 
conversations. These phases, which represent the content-related components of the coaching process and which relate to the established phases of change, include: 'Initiating the dialogue, 'Formulating the concern', 'Defining goals', 'Co-constructing change,' 'Generating measures of action and securing transfer,' 'Evaluation', and 'Concluding the dialogue' (see Figure 1).

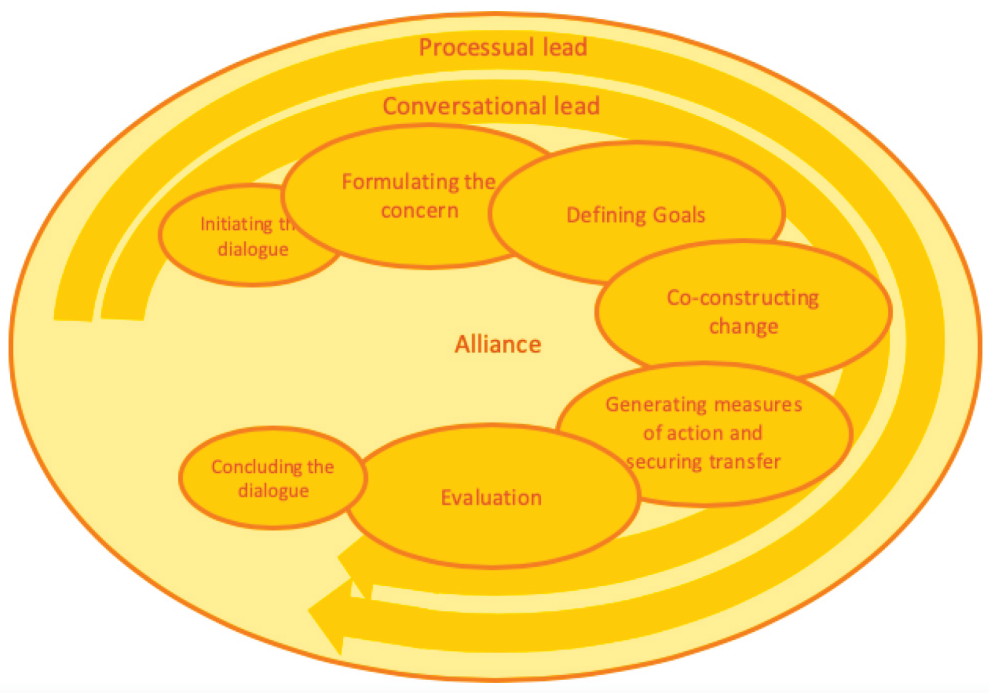

Figure 1: The TSPP Model (adapted from Deplazes et al. 2018)

Whereas both interactants participate in the construction of the content, coaches hold the professional responsibility to steer the coaching conversation and thus to initiate, process and finalize the phases along the coaching process in concordance with their professional agenda. In the model, this is reflected in the 'Processual lead' and 'Conversational lead' components, respectively (Deplazes et al. 2018:75ff). Questioning practices are central in serving this conversational and processual steering purpose (see Section 4). At the same time, participants actively co-construct a working alliance, which serves as the basis upon which the entire coaching interaction relies (Graf \& Spranz-Fogasy 2018b).

For the current research interest in questioning sequences, the TSPP Model allows to carve out their coaching endemic functions as well as their occurrences and frequencies in the course of phases, sessions and entire coaching processes.The model is particularly helpful in the endeavor to address and relate the research foci 'what' (questions in coaching), 'how' (the sequential character of questioning in the unfolding coaching conversation), 'where' (question-answer sequences in the context of specific phases of coaching) and 'how often' (how often do certain question-answer sequences occur in the various phases) and relate these to the global assessment of the effectiveness of the analyzed coaching process. 
Indeed, the model allows to explore which types of questioning sequences occur within a coaching process as well as which questioning sequences initiate, process, and finalize the various above-mentioned phases. It can also provide insights as regards frequencies and functions of question-answer sequences by investigating how often the various types occur within and across phases and what their interaction-type specific change potentials are within and across phases, individual sessions and entire coaching processes. A particular focus when applying this model will be on the relationship between frequency of (un)successful questioning sequences and the local and global effectiveness of the respective coaching process. On a more general level the TSPP Model also gives insights into the appropriate responsive behavior of coaches, as it allows to address both their responsive behavior regarding their professional agenda and their responsive behavior on the interactive microlevel with their clients.

Yet, to eventually put this model into practice, a mixed-methods research design will be necessary that integrates qualitative and quantitative methods from the realms of psychology and linguistics. It must be applied to authentic coaching processes that are video-taped and linguistically transcribed and whose overall, global effectiveness has been assessed with the help of accompanying questionnaires for both coach and client. The development of such an interdisciplinary, mixed-methods research design is currently under way.

\section{Conclusion and Outlook}

Coaching is effective, coaching is professional talk-in-interaction and coaching relies on questions as a core intervention. In order to truly understand this powerful communicative tool in executive coaching and how it contributes to the effectiveness of coaching, we need to move from the decontextualized, monological and idealized portrayal of question types in practice literature and from coding pre-defined and isolated question types (in staged coaching conversations) towards analyzing the authentic use of questioning sequences across coaching conversations as practiced by Conversation Analysis. Still, while such turn-by-turn analysis of questioning sequences allows to carve out the utterance-by-utterance transformation that contributes to the local process of change, the approach is limited as regards analyzing how such questioning sequences functionally, formally and numerically relate to phases of change that span the continuum of coaching sessions. To overcome this restriction, this article argued for an interdisciplinary cooperation between psychology and linguistics. Combining knowledge about established phases of change and about how such phases are locally and sequentially co-constructed on the conversational micro-level allows researchers to provide a more detailed description of how effectiveness emerges in coaching conversations. More specifically argued, concerns about 'how', 'where' and 'how often' of the target 
action 'questioning sequence' can thus be addressed and both its contribution to the local turn-by-turn and the global process effectiveness can be unraveled. As a first concrete product of the envisioned interdisciplinary cooperation, our programmatic article lead up to the presentation of the TSPP Model by demonstrating the omnipresence of questions in practice literature, indicating the existing research gap and arguing for the need to focus on sequences instead of isolated questions. Yet, while this model serves as a matrix against which authentic coaching data can be analyzed, a concrete research project must be built on both qualitative and quantitative methods assembled in a complex mixed-methods research design. It goes without saying that such an endeavor of joining forces is challenging due to diverging theories of science and research logics; still, we are convinced that nothing but such a joint endeavor allows for truly unraveling the local and global change potentials of questioning sequences in helping interactions such as coaching.

\section{References}

Bachkirova, Tatiana; Elaine Cox; and David Clutterbuck. 2018. Introduction. The complete handbook of coaching, $3^{\text {rd }}$ ed., ed. by [Elaine Cox, Tatiana Bachkirova, and David Clutterbuck], xxix-xiviii. London: Sage.

Bartesaghi, Mariaelena. 2009. Conversation and psychotherapy: how questioning reveals institutional answers. Discourse Studies 11(2):153-177.

Behrendt, Peter. 2006. Wirkung und Wirkfaktoren von psychodramatischem Coaching - Eine experimentelle Evaluationsstudie. Zeitschrift für Psychodrama und Soziometrie 5(1):59-87.

Bercelli, Fabrizio; Federico Rossano; and Maurizio Viaro. 2008. Clients' responses to therapists' reinterpretations. Conversation analysis and psychotherapy, ed. by [Anssi Peräkylä, Charles Antaki, Sanna Vehviläinen, and Ivan Leudar], 43-61. Cambridge: CUP.

Bercelli, Fabrizio; Federico Rossano; and Maurizio Viaro. 2013. Supra-session courses of action in psychotherapy. Journal of Pragmatics 57:118-137.

Braunstein, Katharine; and Anthony M. Grant. 2016. Approaching solutions or avoiding problems? The differential effects of approach and avoidance goals with solution-focused and problem-focused coaching questions. Coaching: An International Journal of Theory, Research and Practice 9(2):93-109.

Bungay Stanier, Michael. 2016. The coaching habit: Say less, ask more and change the way you lead forever. Toronto: Box of Crayons Press.

Burt, Daniel; and Zenobia Talati. 2017. The unsolved value of executive coaching: A meta-analysis of outcomes using randomised control trial studies. International Journal of Evidence Based Coaching and Mentoring 15(2):17-24.

Clayman, Steven E.; and Laura Loeb. 2018. Polar questions, response preference, and the tasks of political positioning in journalism. Research on Language and Social Interaction 51(2):127-144. 
De Haan, Erik; Colin Bertie; Andrew Day; and Charlotte Sills. 2010. Critical moments of clients and coaches: A direct-comparison study. International Coaching Psychology Review 5(2):109-128.

De Meuse, Kenneth P.; Guangrong Dai; and Robert J. Lee. 2009. The effectiveness of executive coaching: Beyond ROI? Coaching: An International Journal of Theory, Research and Practice 2(2):117-134.

Deplazes, Silvia. 2016. KaSyCo: Kategoriensysteme zur Analyse von Coachingprozessen. Kassel: Kassel University Press.

Deplazes, Silvia; Eva-Maria Graf; and Hansjörg Künzli. 2018. Das TSPP-Model. Eine Blaupause für die Coaching-Prozessforschung. Coaching | Theorie \& Praxis. DOI: 10.1365/s40896-018-0025-0.

Deppermann, Arnulf. 2015. Wissen im Gespräch: Voraussetzung und Produkt, Gegenstand und Ressource. Interaction and Linguistic Structures 57:1-31.

Drath, Karsten. 2012. Coaching und seine Wurzeln. Freiburg, München: Haufe Gruppe.

Drew, Paul; and John Heritage (eds). 1992. Talk at work. Interaction in institutional settings. Cambridge: CUP.

Drew, Paul; and Elizabeth Couper-Kuhlen. 2014. Requesting in social interaction. Amsterdam: John Benjamins.

Elliott, Robert. 2010. Psychotherapy change process research. Psychotherapy Research 20(2):123-135.

Elliott, Robert. 2012. Qualitative methods for studying psychotherapy change process. Qualitative research methods in mental health and psychotherapy: A guide for students and practitioners, ed. by [David Harper and Andrew R. Thompson], 69-81. Chichester: Wiley-Blackwell.

Fietze, Beate. 2017. Auf zwei Beinen läuft man besser. Professionelle Beratung braucht Forschung. övs news 2017(1):2-4.

Fillery-Travis, Annette; and Elaine Cox. 2018. Researching coaching. The complete handbook of coaching, $3^{\text {rd }}$ ed., ed. by [Elaine Cox, Tatiana Bachirova, and David Clutterbuck], 518-535. Los Angeles: Sage.

Fischer-Epe, Maren. 2012. Coaching: Miteinander Ziele erreichen. Reinbeck bei Hamburg: Rowholt.

Freed, Alice; and Susan Ehrlich (eds.). 2010. "Why do you ask?" The function of questions in institutional discourse. Oxford: OUP.

Geißler, Harald. 2016. Die Grammatik des Coachens. Wiesbaden: Springer.

Graf, Eva-Maria. 2015. Kommunikative Basisaktivitäten im Coaching-Gespräch: Ein linguistischer Beitrag zur Coaching-Prozessforschung. Coaching | Theorie \& Praxis. DOI: 10.1365/s40896-015-0001-1.

Graf, Eva-Maria. 2016. Von „so typisch Frau“ bis „jetzt nehmen wir mal Fußball als Beispiel“- Praktiken der diskursiven Herstellung von Weiblichkeit(en) und Männlichkeit(en) im Führungskräfte-Coaching aus genderlinguistischer Sicht. Coaching | Theorie \& Praxis, DOI 10.1365/s40896-016-0015-z.

Graf, Eva-Maria. 2017. Management Coaching - Ein arbeitsweltliches Beratungsgespräch zwischen Selbst-Reflexion und Output Orientierung? Beraten ist Sprechen. Eine linguistische Typologie zu Beratungsgesprächen in verschiedenen Handlungsfeldern, ed. by [Ina Pick], 77-95. F.A.L. Bern: Peter Lang. 
Graf, Eva-Maria. 2019. The pragmatics of executive coaching. Amsterdam: John Benjamins.

Graf, Eva-Maria; and Thomas Spranz-Fogasy. 2018a. Welche Frage, Wann und Warum? Eine qualitativ-linguistische Programmatik zur Erforschung von FrageSequenzen als zentrale Veränderungspraktik im Coaching. Coaching | Theorie und Praxis. DOI:10.1365/s40896-018-0021-4.

Graf, Eva-Maria; and Thomas Spranz-Fogasy. 2018b. Helfende Berufe - Helfende Interaktionen. Handbuch Text und Gespräch, ed. by [Karin Birkner and Nina Janich], 418-442. Amsterdam: de Gruyter.

Graf, Eva-Maria; and Frédérick Dionne. under review. Coaching Research in 2020 - About Destinations, Journeys and Travelers. International Coaching Psychology Review.

Graf, Eva-Maria; and Susanne Kabatnik. in prep.. „Was kann ich da noch tun, um s/ ja das, das, das, das/ die Gespräche, ne, •• die ich führe, $((1,9 s))$ ja noch, • zu noch besseren Ergebnissen führen" - Lösungsorientierte Fragen in FührungskräfteCoaching: Gesprächsanalytische Einblicke in ihr lokales und globales Veränderungspotential

Grant, Anthony M. 2012. Making positive change: A randomized study comparing solution-focused vs. problem-focused coaching questions. Journal of Systemic Therapies 31(2):21-35.

Grant, Anthony M.; and Sean A. O'Connor. 2010. The differential effects of solutionfocused and problem-focused coaching questions: a pilot study with implications for practice. Industrial and Commercial Training 42(2):102-111.

Grant, Anthony M.; and Sean A. O'Connor. 2018. Broadening and building solutionfocused coaching: feeling good is not enough. Coaching: An International Journal of Theory, Research and Practice 11(2):165-185.

Grant, Anthony M; and Benjamin Gerrard. 2019. Comparing problem-focused, solution-focused and problem-focused/solution-focused coaching approach: solution-focused coaching questions mitigate the negative impact of dysfunctional attitudes. Coaching: An International Journal of Theory, Research and Practice. DOI: 10.1080/17521882.2019.1599030

Grant, Anthony M.; and Sean A. O'Connor. 2019. A brief primer for those new to coaching research and evidence-based practice. The Coaching Psychologist, 15(1):3-10.

Greif, Siegfried; Frank Schmidt; and André Thamm. 2012. Warum und wodurch Coaching wirkt. Ein Überblick zum Stand der Theorieentwicklung und Forschung über Wirkfaktoren. OSC Organisationsberatung-Supervision - Coaching, 19(4):375390.

Greif, Siegfried; and Elke Benning-Rohnke. 2015. Konsequente Umsetzung von Zielen durch Coaching: Praktisch nützliche Erkenntnisse aus der Grundlagenforschung und ihre Anwendung. Coaching| Theorie \& Praxis 1(1):25-35.

Hayano, Kaoru. 2013. Question design in conversation. The handbook of conversation analysis, ed. by [Jack Sidnell and Tanya Stivers], 395-414. Malden: Wiley-Blackwell.

Heller, Monica. 2007. Distributed knowledge, distributed power: A sociolinguistics of structuration. Text \& Talk 27(5, 6):633-653. 
Heritage, John. 2010. Questioning in medicine. "Why do you ask?" The function of questions in institutional discourse, ed. by [Alice Freed and Susan Ehrlich], 42-68. New York: Oxford University Press.

Heritage, John. 2012. Epistemics in action. Research on Language and Social Interaction 45(1):1-29.

Heritage, John. 2018. The ubiquity of epistemics: A rebuttal to the 'epistemics of epistemics' group. Discourse Studies. DOI: 10.1177/1461445617734342.

James, Ian; Rachel Morse; and Alan Howarth. 2010. The science and art of asking questions in cognitive therapy. Behavioral and Cognitive Therapy 38(1):83-93.

Jones, Rebecca J.; Stephen A. Woods; and Yves R.F. Guillaume. 2016. The effectiveness of workplace coaching: A meta-analysis of learning and performance outcomes. Journal of Occupational and Organizational Psychology 89:249-277.

Kabatnik, Susanne; and Eva-Maria Graf. in prep.. Lösungsorientierter Fragen im Coachingund Psychotherapie-Gespräch - ein Gesprächslinguistischer Vergleich ihres Lokalen und Globalen Veränderungspotentials.

Kallmeyer, Werner. 2000. Beraten und Betreuen. Zur gesprächsanalytischen UntersuchungVon helfenden Interaktionen. Zeitschrift für qualitative Bildungs-, Beratungs-, undSozialforschung 2:227-252.

Koester, Almut. 2010. Workplace discourse. London: Continuum.

Köller, Wilhelm. 2004. Perspektivität und Sprache: Zur Struktur von Objektivierungsformen in Bildern, im Denken und in der Sprache. Berlin: De Gruyter.

Kotte, Silia; Denise Hinn; Katrin Oellerich; and Heidi Möller. 2016. Der Stand der Coachingforschung: Kernergebnisse der vorliegenden Metaanalysen. Zeitschrift für Organisationsberatung, Supervision und Coaching. DOI: 10.1007/s11613-0160444-6.

Kramer, Ueli; and William B. Stiles. 2015. The responsiveness problem in psychotherapy: A review of proposed solutions. Clinical Psychology: Science and Practice 22(3):277-295.

Künzli, Hansjörg. 2013. Die andere Seite von Coaching: zu Risiken und Nebenwirkungen lesen Sie die Packungsbeilage. Coaching Magazin 4:52-56.

Lee, Seug-Hee. 2013. Response design in conversation. The handbook of conversation analysis, ed. by [Jack Sidnell and Tanya Stivers], 415-432. Malden: Wiley-Blackwell.

Loebbert, Michael; and Christa Wilmes. 2013. Coaching als Beratung. Professional Coaching. Konzepte, Instrumente, Anwendungsfelder, ed. by [Michael Loebbert], 1748. Stuttgart: Schäffer Poeschel.

Mack, Christina; Christoph Nikendei; Johannes C. Ehrenthal; and Thomas SpranzFogasy. 2016. „[...] hab ich glaub ich die richtigen fragen gestellt.“ Therapeutische Fragehandlungen in psychodiagnostischen Gesprächen. OPAL 2016(3):1-98.

MacMartin, Clare. 2008. Resisting optimistic questions in narrative and solutionfocused therapies. Conversation analysis and psychotherapy, ed. by [Anssi Peräkylä, Charles Antaki, Sanna Vehviläinen, and Ivan Leudar], 80-99 Cambridge: CUP.

Marciniak, Agnieszka; Christoph Nikendei; Johannes Ehrenthal; and Thomas Spranz-Fogasy. 2016. „... Durch Worte heilen“ - Linguistik und Psychotherapie. Sprachreport 32(3):1-11. 
Mayes, Patricia (2020) The Role of Recipient Questions in Progressing Narrative Sequencesin Aided Communication. Scandinavian Studies in Language, 11(1), 117-145.

Mayring, Philipp. 2010. Qualitative Inhaltsanalyse. Grundlagen und Techniken. Weinheim: Beltz.

McGee, Dan. 1999. Constructive questions: How do therapeutic questions work? Unpublished doctoral dissertation, University of Victoria.

McGee, Dan; Augustin Del Vento; and Janet Bavelas. 2005. An interactional model of questions as therapeutic interventions. Journal of Marital and Family Therapy 31(4):371-384.

Mondada, Lorenza. 2013. Conversation analysis and institutional interaction. The Encyclopedia of Applied Linguistics, ed. by [Carol A. Chapelle], 1005-1011. Oxford: Blackwell.

Mönnich, Annette. 2004. Gesprächsführunglernen: Welche impliziten Konzeptualisierungen des Kommunikationslernens sind in Methoden zur Entwicklung der Gesprächsfähigkeit zu finden? Analyse und Vermittlung von Gesprächskompetenz, ed. by [Michael Becker-Mrotzek and Gisela Brünner], 87112. Radolfzell: Verlag für Gesprächsforschung.

Muntigl, Peter. 2013. Resistance in couples counselling. Journal of Pragmatics 49:1837.

Muntigl, Peter; and Adam O. Horvath. 2014. The therapeutic relationship in action: How therapists and clients co-manage relational disaffiliation. Psychotherapy Research 24(3):327-345.

Muntigl, Peter; and Loreley Hadic Zabala. 2008. Expandable responses: How clients get prompted to say more during psychotherapy. Research on Language and Social Interaction 41(2):187-226.

Neipp, Maria del Carmen; Mark Beyebach; Rosa María Núñez Núñez; and MarieCarmen Martínez-González. 2015. The effect of solution-focused versus problemfocused questions: a replication. Journal of Marital and Family Therapy 42(3):525535.

Newsom, Glenn; and Eric Dent. 2011. A work behaviour analysis of executive coaches. International Journal of Evidence Based Coaching and Mentoring 9(2):1-22.

Peräkylä, Anssi. 1995. Aids counseling. Institutional interaction and clinical practice. Cambridge: CUP.

Peräkylä, Anssi. 2011. After interpretation: third position utterances in psychoanalysis. Research on Language and Social Interaction 44(3):288-316.

Peräkylä, Anssi. 2019. Conversation Analysis and Psychotherapy: Identifying Transformative Sequences. Research on Language and Social Interaction 52(3):257280.

Pick, Ina (ed.). 2017. Beraten ist Sprechen. Eine linguistische Typologie zu Beratungsgesprächen in verschiedenen Handlungsfeldern. F.A.L. Bern: Peter Lang.

Pomerantz, Anita; and John Heritage. 2013. Preference. The handbook of conversation analysis, ed. by [Jack Sidnell and Tanya Stivers], 210-228. Malden: Wiley-Blackwell.

Raymond, Geoffrey. 2018. Which epistemics? Whose conversation analysis? Discourse Studies. DOI: 10.1177/1461445617734343. 
Sarangi, Srikant. 2001. On demarcating the space between 'lay expertise' and 'expert laity'. Text 21(1 and 2):3-11.

Sarangi, Srikant. 2010. The spatial and temporal dimensions of reflective questions in genetic counseling. "Why do you ask?" The function of questions in institutional discourse, ed. by [Alice Freed and Susan Ehrlich], 235-255. New York: OUP.

Schegloff, Emanuel. 2007. Sequence organization in interaction: a primer in conversation analysis. Cambridge: CUP.

Schreyögg, Astrid. 2012. Coaching. Eine Einführung für Praxis und Ausbildung, 2nd edition. Frankfurt, New York: Campus Verlag.

Schreyögg, Astrid; and Christoph Schmidt-Lellek (eds). 2007. Konzepte des Coaching. Sonderheft Organisationsberatung Supervision Coaching.

Sidnell, Jack; and Tanya Stivers (eds.). 2013. The handbook of conversation analysis. Malden: Wiley-Blackwell.

Sonesh, Shirley C.; Chris W. Coultas; Christina N. Lacerenza; Shannon L. Marlow; Lauren E. Benishek; and Eduardo Salas. 2015. The power of coaching: a metaanalytic investigation. Coaching: An International Journal of Theory, Research and Practice 8(2):73-95.

Spranz-Fogasy, Thomas. 1992. Ärztliche Gesprächsführung - Inhalte und Erfahrungen gesprächsanalytisch fundierter Weiterbildung. Kommunikationsberatung und Kommunikationstraining. Anwendungsfelder der Diskursforschung, ed. by [Reinhard Fiehler and Wolfgang Sucharowski], 68-78. Opladen: Westdeutscher Verlag.

Spranz-Fogasy, Thomas. 2005. Kommunikatives Handeln in ärztlichen Gesprächen. Psychosomatische Gesprächsführung in der Frauenheilkunde. Ein interdisziplinärer Ansatz zur verbalen Interaktion, ed. by [Mechthild Neises, Susanne Ditz, and Thomas Spranz-Fogasy], 17-47. Stuttgart: Wissenschaftliche Verlagsgesellschaft.

Spranz-Fogasy, Thomas. 2010. Vestehensdokumentation in der medizinischen Kommunikation: Fragen und Antworten im Arzt-Patient-Gespräch. Verstehen in professionellen Handlungsfeldern, ed. by [Arnulf Deppermann, Ulrich Reitemeier, Reinhold Schmitt, and Thomas Spranz-Fogasy], 27-116. Tübingen: Gunter Narr.

Spranz-Fogasy, Thomas; Eva-Maria Graf; Johannes C. Ehrenthal; and Christoph Nikendei. (2019). Beispiel-Nachfragen im Kontext von Veränderung: Elitizierungsund Prozessierungsstrategien in Psychotherapie und Coaching-Gesprächen - Ein Vergleich. Veränderungskommunikation in helfenden Berufen, ed. by [Eva Maria Graf, Claudio Scarvaglieri, and Thomas Spranz-Fogasy]. Tübingen: Gunter Narr.

Spranz-Fogasy, Thomas; Graf, Eva-Maria; Nikendei, Christoph; and Johannes C. Ehrenthal (revised). Requesting Examples in Psychodiagnostic Interviews: Therapists' Contribution to the Sequential Co-construction of Clients' Change. Understanding Change in Helping Professions: Special Issue for Communication and Medicine, ed. by [Joanna Pawelczyk and Eva-Maria Graf].

Steensig, Jakob; and Paul Drew. 2008. Introduction: Questioning and affiliation/ disaffiliation in interaction. Discourse Studies 10(1):515.

Stein, Irene. 2007. Enacting the role of coach. Discursive identities in professional coaching discourse. Doctoral dissertation, Fielding Graduate University.

Stivers, Tanya. 2010. An overview of the question-response system in American English conversation. Journal of Pragmatics 42(10):2772-2781. 
Stivers, Tanya. 2013. Sequence organization. The handbook of conversation analysis, ed. by [Jack Sidnell and Tanya Stivers], 191-209. Malden: Wiley-Blackwell.

Stivers, Tanya. 2018. How we manage social relationships through answers to questions: The case of interjections. Discourse Processes. DOI:10.1080/016385 3X.2018.1441214

Stivers, Tanya; and Jeffrey D. Robinson. 2006. A preference for progressivity in interaction. Language in Society 35(3):367-392.

Stokoe, Elizabeth; and Rein Sikveland. 2016. Formulating solutions in mediation. Journal of Pragmatics 105:101-113.

Tertocha, Meike. 2016. Vergleich der Coachingqualität von Experten und Novizen. Master's Thesis, Universität Freiburg.

Theeboom, Tim; Bianca Beersma; and Annelies van Vianen. 2014. Does coaching work? A meta-analysis on the effects of coaching on individual level outcomes in an organizational context. The Journal of Positive Psychology 9(1):1-18.

Theeboom, Tim; Bianca Beersma; and Annelies van Vianen. 2016. The differential effects of solution-focused and problem-focused coaching questions on the affect, attentional control and cognitive flexibility of undergraduate students experiencing study-related stress. The Journal of Positive Psychology 11(5):460-469.

Tiittula, Liisa. 2001. Formen der Gesprächssteuerung. Text- und Gesprächslinguistik: Ein internationales Handbuch zeitgenössischer Forschung, volume 2 (HSK 16.2), ed. by [Klaus Brinker], 1361-1374. Berlin: De Gruyter.

Tracy, Karen; and Jessica Robles. 2009. Questions, questioning, and institutional practices: an introduction. Discourse Studies 11(2):131-152.

Tsui, Amy. 1992. A functional description of questions. Advances in spoken discourse analysis, ed. by [Malcolm Coulthard], 89-110. London: Routledge

Voutilainen, Liisa; Anssi Peräkylä; and Johanna Ruusuvuori. 2011. Therapeutic change in interaction: conversation analysis of a transforming sequence. Psychotherapy Research 21(3):348-365.

Voutilainen, Liisa; Federico Rossano; and Anssi Peräkylä. 2018. Conversation analysis and psychotherapeutic change. Longitudinal studies on the organization of social interaction, ed. by [Simona Pekarek Doehler, Johannes Wagner, and Esther González-Martínez], 225-254. London: Palgrave MacMillan.

Weatherall, Ann; and Marion Gibson. 2015. "I'm going to ask you a very strange question": A conversation analytic case study of miracle technique in solutionbased therapy. Qualitative Research in Psychology 15(2):162-181.

Wegener, Robert. 2019. Bedeutsame Momente im Coaching. Wiesbaden: Springer.

Wegener, Robert; Michael Loebbert; Agnes Fritze; and Marianne Hänseler (eds). 2018. Coaching-Prozessforschung. Forschung und Praxis im Dialog. Göttingen: Vandenhoeck \& Ruprecht.

Wehr, Thomas. 2010. The phenomenology of exception times: Qualitative differences between problem-focused and solution-focused interventions. Applied Cognitive Psychology 24(4):467-480.

Wehrle, Martin. 2012. Die 500 besten Coaching-Fragen. Bonn: ManagerSeminare Verlag.

Weiste, Elina; and Anssi Peräkylä. 2013. A comparative conversation analytic study of formulations in psychoanalysis and cognitive psychotherapy. Research on Language and Social Interaction 46(4):299-321. 
Whitworth, Laura; Karen Kimsey-House; Henry Kimsey-House; and Philipp Sandahl. 1998. Co-active coaching. New skills for coching people toward success in work and life. Palo Alto: Davis Black Publishing.

Worsøe, L. B., \& Jensen, T. W. (2020). Questioning questions in psychotherapeutic practice:The dialogical dynamics of change in therapy through clients questioning therapists. Scandinavian Studies in Language, 11(1), 279-317. 